\title{
The history and development
}

\section{of libraries in}

\section{American higher education}

\author{
By Plummer Alston Jones Jr. \\ Head Librarian \\ Elon College
}

\begin{abstract}
An executive briefing for administrators and potential donors.
\end{abstract}

\begin{abstract}
C College and university librarians in managerial positions are called upon daily to justify the existence of academic libraries in terms of their missions, goals, and objectives: to other academic administrators and potential donors, for increases in budgets or funding for special projects; and to various library user groups, for compliance with policies affecting services and resources. In both cases, it behooves academic library managers to be able to present accurately, succinctly, and without library jargon, the reasons why their libraries need to keep up with nationwide trends and, in rare cases, to promote further changes and innovations.

The following executive briefing summarizes the history and development of libraries in American higher education and thus provides the historical context in which decisions affecting academic libraries today are made. The briefing was used initially to inform the Elon College Friends of the Library regarding the state of academic libraries, specifically the problems and the challenges facing them, and ultimately to demonstrate the need for external support groups such as the Friends. Later, excerpts from the briefing were used to justify a special request proposal for the retrospective con-
\end{abstract}

version of the Elon College Library's holdings to a machine-readable format as a major component in the move toward the automation of the library.

The intent behind the sharing of this briefing is to provide data which college and university library managers can tailor for use in their own unique situations and to serve as a stimulus to the publication of other such data for the benefit of the academic library community. No sound decision is made in a vacuum, but often librarians and other academic administrators do not share a body of knowledge upon which to base effective communication. A briefing such as this is an attempt to provide a common ground on which decisions can be made.

\section{Executive briefing}

American college and university libraries have always reflected the fortunes of their respective institutions, sharing in their poverty and their prosperity, and reflecting in varying degrees the character and tendencies of their curricula and instructional methods.

Nine colonial colleges were established and had libraries by 1792 . The libraries were never large; 
even Harvard, the oldest and largest, had fewer than 13,000 volumes prior to 1800 . Private donations from library-minded individuals on both sides of the Atlantic furnished the greatest number and best quality of books; however, funds to purchase books were also secured from special tax revenues, fees assessed students and trustees, and even lotteries. Despite limited resources and restricted access to them, compounded by abbreviated hours of opening, colonial college libraries provided the curricular support for programs designed to train young men for the ministry. Theology was, therefore, the most generously represented discipline in colonial college library collections, with the classics, philosophy, and history next in prominence.

Most of the data on college libraries of the 19th century is gleaned from the records of the colleges themselves and from a major survey of libraries undertaken by Charles Coffin Jewett for the Smithsonian Institution in 1850. At the time of this survey, there were only five collections in the United States that numbered over 50,000 volumes and only two of these were at colleges, Harvard and Yale, the "twin seats of learning."

The smallness of the collections at most colleges made a special library building unnecessary. Libraries often shared facilities with other college departments and, in many cases, the college library was distributed among the professors, each professor having charge of the books pertaining to his discipline. The first building constructed exclusively for library purposes was at South Carolina College (later the University of South Carolina) in 1840, built at a cost of $\$ 22,000$.

The slowness of growth of collections was due to the small number of books and magazines available, with only a little over 39,000 titles published during the entire period from 1639 to 1800 , according to Charles Evans's authoritative American Bibliography: A Chronological Dictionary. Most publications had to be imported from England and Europe.

The fixed character of the curriculum of 19thcentury colleges and slow, if any, changes in instructional methods retarded the growth of libraries. Most instruction did not require the regular use of a large number of books. The infamous, but nevertheless influential, Yale Report of 1828 implied that a single text supplemented by recitations was superior to the unsupervised use of the library. The philosophy of learning embodied in this report effectively suppressed curricular and instructional reforms as well as library development for decades.

Since the library made small provision for contemporary literature and general reading materials of a popular nature, and the few hours of opening were chiefly for checking out and returning books only, students in literary and debating societies formed their own libraries. These society libraries often excelled in quality and exceeded in size the college library itself.
The influence of the Morrill Acts of 1862 and 1890 combined to turn the attention of higher education away from its classical traditions to the practicalities of present needs. In addition to this reorientation of the college curriculum, the founding of Johns Hopkins in 1876, using the German university as its model, emphasized for the first time the research function of higher education, an emphasis followed by Harvard, Cornell, Columbia, and other universities in the vanguard. Thus the library gained increasing recognition as essential to the new academic role of research and worthy of the epithet "the heart of the university." Along with this recognition came rapidly increasing annual budgets for books and periodicals, for the erection of separate library buildings to provide good working conditions for students, scholars, and librarians, and for the extension of hours of opening to at least five days per week and often on weekends.

Concurrently, the beginnings of the professionalization of American librarianship occurred in 1876 when the American Library Association was founded. Library education followed shortly thereafter in 1887 with the opening of Melvil Dewey's library school at Columbia, followed by library schools at Pratt, Drexel, and others. Women slowly began to receive recognition as heads of library schools and directors of academic libraries. The employment of library staffs headed by professionally trained librarians became the norm across the nation.

Several noticeable trends emerged in college and university libraries at the turn of the 20th century. A shift in emphasis from conservation and protection of library materials to putting them to effective use in the hands of the faculty and students was more and more the dominant attitude. An obligation to provide effective personal service and education in the use of the library was due, at least in part, to the recognition of the library's role as an educational force independent of its curricular support function. The necessity of classifying books according to subject and not to fixed shelf location, cataloging books with greater bibliographic detail and with more access points in the card catalog, and the practice of putting books on reserve when intensive research use was anticipated, all led to better use of the collection. The appearance of subject-oriented departmental libraries in addition to the central campus library was seen on many college and university campuses. A move toward cooperation between libraries, principally in the loan of materials, led to the adoption of the Interlibrary Loan Code of 1919, whereby academic libraries throughout the nation cooperated in external borrowing agreements. Finally, the recognition of the worth of popular reading materials, previously considered unsuitable, prepared the way for the gradual absorption of the literary and debating society libraries by the central campus library.

After 1900, there was an emerging emphasis on 
the need of students to participate in self-education through independent study, a trend which prompted more direct attention to the library as not only an agency for curricular support but also as an instrument of self-instruction. By 1928 the Carnegie Corporation was dangling grants before the eyes of eager college administrators to be used to encourage the further integration of the library into the instruction in liberal arts colleges.

The further professionalization of librarianship was evidenced by the formation of the Association of Research Libraries (ARL) in 1932 and the Association of College and Research Libraries (ACRL) in 1938. Supported by the unprecedented shortage of libraries brought about by World War II and by the realization that library work was then much more complex, the profession upgraded its professional education requirement from the bachelor's to the master's degree.

One noted librarian has employed a Dickensian phrase to describe the post-World War II era, calling it the best of times, the worst of times for college and university libraries. On the plus side were: 1) the great expansion of enrollments on campuses and a tremendous building boom;2) increased funding for libraries through institutional budgets as well as outside funding from the Federal government and private corporations; 3) technological advances, particularly microreproduction technology and the computer, both making library operations much more manageable; and 4) the opportunity to serve new needs for advanced study and research in ever increasing fields and area studies. On the negative side were, in addition to the gen- eral complexity of library operations, especially in university settings: 1) the information explosion accompanying these new curricular developments; 2) criticism now aimed directly at the library when research demands were not met; and 3) threats to the security of library collections which surfaced with a vengeance.

The building boom for libraries began in the late 1940 s and continued into the 1950s and 1960s. Federal money in the form of grants from the Higher Education Facilities Act of 1963, although discontinued in 1969 , provided for the construction of 605 separate library buildings throughout the nation. Two federal programs, both a part of the Higher Education Act of 1965, provided assistance to libraries: 1) Title II-A, aimed at college libraries, granted funds for acquisitions and, later, networking; and 2) Title II-C, aimed at major research libraries, granted funds for collection development in subject areas of national importance.

Until the 1970s there was an acute shortage of professional librarians; then, almost overnight, there was a surplus due in part to the expansion of programs of existing library schools and the birth of new library schools. Preservation of collections from theft and mutilation and protection of library buildings from vandalism and library patrons from physical harm have been major issues calling for the installation of sensor devices to detect book theft and the employment of security guards to patrol buildings and to protect patrons during everincreasing hours of opening.

The growth of networks and consortia in the 1980 s was the natural outcome of the proliferation

\section{Time line for the development of academic libraries}

1792

1800

1828

1840

1850

1862 and 1890

1876

1876

1887

1919

1928

1932 and 1938

$1940 \mathrm{~s}-1960 \mathrm{~s}$

$1970 \mathrm{~s}$

$1980 \mathrm{~s}$
Nine colonial college libraries established

Harvard, oldest and largest college library, with 13,000 volumes

Yale Report retards development of academic libraries and stifles curricular reform

First separate building to house a college library built by South Carolina College (later USC)

Only two college libraries, Harvard and Yale, with collections over 50,000

Morrill Acts promote curricular reform toward practical needs

Founding of Johns Hopkins on the German research university model

American Library Association founded

Melvil Dewey's library school opens at Columbia University

Interlibrary Library Code promotes lending of library materials between libraries

Carnegie Corporation funds college libraries

Founding of Association of Research Libraries (ARL) and Association of College and Research Libraries (ACRL) respectively

Building boom for college libraries and collection development grants funded by Federal government

Preservation and conservation of library materials a concern in light of

vandalism and budget cutbacks

Growth of networks and consortia for library resource sharing 
of materials, services, and needs, coupled with decreased institutional budgets, inflationary costs of library materials, and cutbacks in Federal funding. Cooperation is the byword of the 1980 s as evidenced by the participation of many college and university libraries in cooperative projects for cataloging, acquisitions, literature searching, and interlibrary loan, all these operations being enhanced by the miraculous capabilities of the computer.

The future of college and university libraries will depend largely on the commitment of librarians and educators to resource sharing and the provision of traditional as well as innovative services in a network environment.

\section{References}

Brough, Kenneth. "The Colonial College Library," in Michael H. Harris, ed., Reader in American Library History (Washington, D.C.: NCR Microcard Editions, 1971), 31-32.

Chattin Carlton, W. N. "College Libraries in the Mid-Nineteenth Century," Library Journal 32
(November 1907): 479-86.

Clayton, Howard. "The American College Library, 1800-1860," in Harris, Reader in American Library History, 89-98.

Govan, James F. "Collegiate Education: Past and Present," Library Trends 18 (July 1969): 13-28.

Hamlin, Arthur T. The University Library in the United States: Its Origins and Development (Philadelphia: University of Pennsylvania, 1981), 3-83.

Holley, Edward G. "Academic Libraries in 1876," in Richard D. Johnson, ed., Libraries for Teaching, Libraries for Research: Essays for a Century (Chicago: American Library Association, 1977), 1-33.

Shiflett, Orvin Lee. Origins of American Academic Librarianship (Norwood, N.J.: Ablex, 1981), 1-55.

Shores, Louis. Origins of the American College Library, 1638-1800 (Nashville, Tenn.: George Peabody College, 1934), 56, 226-32.

Veit, Fritz. "Library Service to College Students," Library Trends 25 (July 1976) : 361-78.

\title{
The Academy and the future:
}

\section{Constancy within change}

\author{
By Jonathan F. Fanton \\ President \\ New School for Social Research
}

\section{A paper presented at the November 18, 1988, meeting of the ACRL Greater New York Metropolitan Area Chapter.}

$\mathbf{T}$ he prospect of reflecting on what the Academy will look like in the 2 Ist century, and what the implications are for libraries and librarians, is daunting. It brings to mind Felix Frankfurter's words: "...to pierce the curtain of the future, to give shape and visage to mysteries still in the womb of time, is the gift of imagination." My imagination has enough trouble getting through the next year let alone into the next century. The daily pressures of fund raising, budget planning, faculty appointments, and myriad activities that absorb a president's life, led me to think for a moment I should pass up your invitation. But I remembered that in the early hours of J anuary first, I resolved to accept 